\title{
Międzynarodowe bezpieczeństwo Polski w myśli politycznej głównych nurtów polskiej prawicy obecnych w Akcji Wyborczej Solidarność
}

\section{International Security of Poland in political thought of main streams of Polish right in the 1990s.}

The aim of this article is to present and analyse the concepts of international security by Polish right-wing parties in the 1990s.

Poland right in many aspects has expressed similar views on the international relations. Universal consensus were concerning the European integration, accession to NATO, and close cooperation with the United States.

Słowa klucze: Akcja Wyborcza Solidarność, polska myśl polityczna, bezpieczeństwo w myśli politycznej, Arkadiusz Lewandowski, bezpieczeństwo międzynarodowe Polski, prawica a bezpieczeństwo

Pierwsze 10 lat po odzyskaniu na nowo niepodległości to dla Polski nie tylko transformacja systemu politycznego, ale także zmiana pozycji i znaczenia w relacjach międzynarodowych. Nowe okoliczności polityczne jakie zaczęły kształtować się na świecie po 1989 roku sprawiły, że przed państwem polskim pojawiły się zarówno nieosiągalne dotąd szanse rozwoju ale i zagrożenia dla jego bezpieczeństwa. Sytuacja ta wymagała od przedstawicieli klasy politycznej nie tylko bieżącego komentowania i analizowania ewentualnych zagrożeń, ale również tworzenia propozycji planów na przyszłości. Przed takim wyzwaniem stawali m.in. politycy i ugrupowania polityczne uznawane za prawicowe, którzy z pierwszych 10 lat Trzeciej Rzeczypospolitej blisko połowę tego czasu stanowili zaplecze poszczególnych gabinetów rządowych.

Celem niniejszego artykułu jest określenie podstawowych wyznaczników koncepcji zapewnienia międzynarodowego bezpieczeństwa Polski w optyce głównych 
środowisk i partii prawicowych w latach 90. XX wieku. Cezurę czasową przyjętą w artykule dookreślają z jednej strony: początek transformacji systemowej w Polsce z drugiej zaś rok 2001 i wygrana Sojuszu Lewicy Demokratycznej oraz atak terrorystyczny w Nowym Jorku, który zmienił znacząco postrzeganie zagadnienia bezpieczeństwa międzynarodowego.

$\mathrm{Na}$ potrzeby tekstu za środowiska i partie prawicowe rozumieć będziemy przedstawicieli ugrupowań, które współtworzyły nurty: chrześcijańsko-demokratyczny, konserwatywny oraz chrześcijańsko-narodowy, czyli te które na koniec dekady instytucjonalnie „okrzepły” stanowiąc podstawę Akcji Wyborczej Solidarność w postaci odpowiednio: Porozumienia Polskich Chrześcijańskich Demokratów, Stronnictwa Konserwatywno-Ludowego oraz Zjednoczenia Chrześcijańsko-Narodowego.

Samo pojęcie prawicy i jego znaczenie budzi kontrowersje w obrębie nauk o polityce. Pojęcie to (podobnie jak i „lewica”) współcześnie uznawane jest niekiedy za nieadekwatne do opisu rzeczywistości politycznej. Kierunki tej krytyki, według Waldemara Wojtasika, skierowane zostały na nieprawidłowość samego podziału lewica-prawica, zbytnią ogólność tych pojęć i wzajemne przenikanie się elementów je różnicujących ${ }^{1}$.

Roman Bäcker dodaje, że niemożliwym jest stworzenie „takiej definicji prawicy i lewicy, która obejmowałaby wszystkie przypadki ugrupowań, które są tak nazywane albo się autoidentyfikują jako takie" ${ }^{2}$. Co więcej, pojęcia te należałoby ujmować jako kontekstualne oraz ograniczone tak czasowo, jak i terytorialnie, co oznacza, że nie mogą być wykorzystywane jako kategorie teoretyczne. Konstatując można za autorem tej koncepcji stwierdzić: „Ich używanie (pojęć „prawica” i „lewica” - przyp. A. L.) jest sensowne tylko w sytuacji określania wobec siebie relacji ugrupowań parlamentarnych w danym systemie politycznym i danym czasie" 3 .

Obok negatywnych opinii w dyskursie naukowym funkcjonują również głosy zwolenników aktualności diady lewica-prawica. Aleksander Hall sugeruje, że podział na te kategorie jest nadal aktualny w opisie rzeczywistości, choć nie do końca jest on taki sam jak kiedyśs . Zwolennikiem utrzymania aktualności tych pojęć był również Norberto Bobbio, autor książki o wiele mówiącym tytule „Prawica i Lewica”, który stwierdzał, że „Prawica i lewica to dwa terminy antytetyczne, od ponad dwóch stuleci używane powszechnie w celu wskazania sprzeczności po-

Zob. W. Wojtasik, Lewica i prawica w Polsce. Aspekty ekonomiczno-spoteczne, Sosnowiec 2011, s. 31-34.

R. Bäcker, Nietradycyjna teoria polityki, Toruń 2011, s. 146.

Ibidem.

4 A. Hall, Historia francuskiej prawicy, Kraków 2009, s. 10. 
między ideologiami i ruchami, na jakie podzielone jest głęboko skonfliktowane uniwersum myśli i działań politycznych"5.

Określając pojęcie prawicy można za Wojtasikiem powiedzieć, że jest ono niedookreślone, co wynika ze zmieniających się sposobów jego pojmowania na przestrzeni rozwoju politycznego i społecznego ${ }^{6}$. Niemniej jednak prawicowość partii wiąże się z katalogiem wyrażanych prze nie postulatów ${ }^{7}$. Dzięki niemu możemy określić, definicyjne minimum. Według Jacka Bartyzela wspominany katalog tworzą: uznanie nadprzyrodzonego źródła władzy oraz prawno-naturalnego fundamentu społeczeństwa, państwa i prawa; instytucje, takie jak małżeństwo, rodzina, własność prywatna oraz ograniczona wobec nich rola państwa jedynie do funkcji ochronnych, silna władza i ograniczony rząd; poszanowanie dla tradycji i patriotyzmu ${ }^{8}$. Z kolei Aleksander Hall za Rogerem Scrutonem upatruje minimum prawicowości w takich elementach, jak: poparcie i wiara w tradycję, wierność jako podstawy więzi społecznych, związek prawa i moralności, konserwatyzm kulturowy, zasada dziedziczności, własność prywatna jako naturalne uprawnienie i niezbędny filar życia społecznego, wolność jednostki względem zbiorowości, wolny rynek i wolna przedsiębiorczość ${ }^{9}$. Wspomniany już Wojtasik natomiast sedno prawicowości łączy z wartościami religijnymi, tradycyjnymi normami obyczajowymi, wartościami narodowymi, personalizmem, dużą rolą rodziny z autorytetem rodziców, niskimi podatkami, wolnym rynkiem, silną armią i policją ${ }^{10}$. Niemniej jednak, jak zauważa Wojtasik, prawica jest wewnętrznie podzielona i nie wszystkie te elementy muszą stanowić w konkretnym przypadku o prawicowości ${ }^{11}$.

Znamienne jest również, że ideowy i polityczny wizerunek prawicy w różnych krajach wyrasta nie tylko z powszechnych prawicowych wartości, ale również ze specyfiki narodowej i historii ${ }^{12}$. W przypadku polskim rzeczywiście prawica charakteryzuje się swoistą oryginalnością ${ }^{13}$, dlatego też przy definiowaniu prawicy

5 N. Bobbio, Prawica i lewica, Kraków 1996, s. 25.

6 W. Wojtasik, op. cit., s. 35.

Ł. Tomczak, Lewica i prawica w polskim systemie partyjnym 1989-2009, [w:] Transformacja systemowa w Polsce 1989-2009: próba bilansu, red. R. Glajcar, W. Wojtasik, Katowice 2009, s. 107.

8 J. Bartyzel, Prawica, [w:] Encyklopedia polityczna, red. J. Bartyzel, B. Szlachta, A. Wielomski, Radom 2007, s. 321-323.

9 R. Scruton Stownik myśli politycznej, Poznań 2002, przeł. T. Bieroń, s. 301-302, za: A. Hall, Historia francuskiej prawicy, Kraków 2009, s. 14-15.

10 W. Wojtasik, op. cit., s. 38-39.

11 Ibidem.

12 A. Hall, op. cit., s. 13.

13 Na podział lewica-prawica nakłada się podział postkomunistyczny opisany przez Mirosławę Grabowską. Zob. M. Grabowska, Podziat postkomunistyczny. Spoteczne podstawy polityki w Polsce po 1989 roku, Warszawa 2004, s. 163 i nast. 
warto pamiętać i o tym aspekcie. W tym kontekście Rafał Matyja charakteryzował polską prawicę jako wielonurtową chrześcijańską demokrację z wyraźnymi podziałami na tle stosunku wobec integracji europejskiej i atlantyckiej oraz wobec rozwiązań gospodarczych. Natomiast głównych spoiw polskiej prawicy upatrywał w powszechności akceptacji dla wiary katolickiej, silnym poczuciu narodowym i patriotyzmie ${ }^{14}$.

Charakteryzując polską prawice można również dodać, że o ile nie było większych wątpliwości w uznaniu przez poszczególne nurty prawicowe w Polsce jednolitych wyznaczników w sferze tożsamościowej, w postaci wartości chrześcijańskich, roli rodziny czy nawet antykomunizmu, to jednak najsilniejsze podziały miały miejsce w ramach koncepcji gospodarczych (od etatystycznych po silnie wolnorynkowe) oraz roli związków zawodowych w państwie ${ }^{15}$. Uzasadnieniem dla tego faktu może być kwestia genezy głównych sił polskiej prawicy. Rafal Matyja uważa, że w III RP nie istniała tradycja prawicowa sięgająca XIX wieku, a jedynie powstawały prawice jako projekty polityczne. To doprowadziło do sytuacji, że najsilniejszą prawicę zbudowano na bazie związku zawodowego ${ }^{16}$. Miało to swoje przełożenie na profil programowy polskiej prawicy, której główne idee stanowiły: antykomunizm (z czasem antypostkomunizm), obrona postulatów społecznych Kościoła oraz obrona praw ludzi pracy ${ }^{17}$.

\section{Nurt konserwatywny}

Według konserwatystów fundamentem polityki zagranicznej państwa powinien być interes narodowy, natomiast jej główne cele powinny zmierzać do utrwalenia niepodległości oraz zapewnienia bezpieczeństwa zewnętrznego ${ }^{18}$. Rozwinięcie kluczowych dla polskiej polityki zagranicznej zadań pojawiło się w programie politycznym Stronnictwa Konserwatywno-Ludowego z 1997 roku. Trzy główne

14 R. Matyja, Jak nazwać polska prawice, Nowe Państwo 1996, nr 48, s. 5.

15 T. Bojarowicz, Partie i ugrupowania prawicowe w III RP, [w:] Partie i system partyjny III RP, red. K. Kowalczyk, Toruń 2011, s. 155; T. Szawiel, Zróżnicowanie lewicowo-prawicowe i jego korelaty, [w:] Wybory parlamentarne 1997. System partyjny, postawy polityczne, zachowania wyborcze, red. R. Markowski, Warszawa 1999, s. 119-122; K. A. Wojtaszczyk, Prawica i lewica na polskiej scenie politycznej, [w:] Wybory parlamentarne 1991 i 1993, red. S. Gebethner, Warszawa 1995, s. 92; Ł. Tomczak, op. cit., s. 114-115.

16 R. Matyja, Prawica w Polsce: przypadek czy projekt, Rzeczy Wspólne 2010, nr 2, s. 145-146.

17 Ibidem, s. 146.

18 B. Borowik, Myśl konserwatywna, [w:] Myśl polityczna w Polsce po 1989 roku, red. E. Maj, A. Wójcik, Lublin 2008, s. 78. 
filary polityki zagranicznej, dające bezpieczeństwo Polsce jakie zostały tam zaproponowane to: udział w pakcie północnoatlantyckim otwierający szanse na powiązanie z USA, uczestnictwo w UE, ale z uwzględnieniem tradycji narodowych oraz sojusz z niepodległą Ukrainą, jako łącznikiem między Europą Zachodnią i Środkową, a także element pomocny w układaniu stosunków z Rosją ${ }^{19}$. Jak konstatowali twórcy programu: „Są to trzy równorzędne filary polskiej polityki bezpieczeństwa. Tylko triada NATO - Unia Europejska - sojusz z Ukrainą i ugoda z Rosją daje szanse na trwałe bezpieczeństwo Polski w XXI wieku. Takie przekonanie zasadza się zarówno na doświadczeniach płynących z historii Polski, jak i na ocenie sytuacji międzynarodowej" ${ }^{20}$.

Trzeci filar, ograniczony co prawda w programie SKL jedynie do Ukrainy i Rosji, jest nieco mylący. Analizując inne źródła myśli konserwatywnej można zaryzykować tezę, że dotyczył on całej polityki wschodniej państwa polskiego. Sojusz z niepodległą Ukrainą oznaczać miałby formę pomostu pomiędzy Europą Zachodnią i Środkową a regionem euroazjatyckim. Odpowiednie relacje z niepodległą Ukrainą traktowano więc jako kluczowe wobec zachowania równowagi sił w „polskim” regionie Europy oraz konieczne dla osiągnięcia „przyjaznych” stosunków z Rosją ${ }^{21}$.

Wobec procesu integracji z UE w połowie lat 90. XX wieku neokonserwatyści podchodzili z ostrożnością. Formułowali sceptycyzm wobec opiekuńczego wzorca dominującego w UE krępującego rozwój gospodarczy poprzez rozdętą biurokrację. Byli zwolennikami integracji na płaszczyźnie gospodarczej prowadzonej chociażby poprzez znoszenie barier handlowych ${ }^{22}$, polityczną z kolei odsuwając na drugi plan nie usuwając jej jednak całkowicie z horyzontu rozważań. W tym drugim aspekcie opowiadali się za modelem europejskiej wspólnoty ojczyzn, obawiając się jednocześnie wizji wspólnoty bez narodów oraz nadmiernego cedowania uprawnień państw narodowych na rzecz federalistycznej Europy.

Zaznaczyć jednak należy, iż środowiska konserwatywne nie były eurosceptyczne. Rozwój i bezpieczeństwo Polski widziały w kontekście integracji z Unią ${ }^{23}$.

19 Stronnictwo Konserwatywne Ludowe. Program, Warszawa 1997, s. 17-18.

20 Ibidem, s. 17.

21 Zob. szerzej: A. Lewandowski, Wizja polskiej polityki zagranicznej wedle ugrupowań neokonserwatywnych w latach dziewięćdziesiatych XX wieku, [w:] Polityka zagraniczna III RP. 20 lat po przełomie, t. 1, red. A. Jarosz, K. Olszewski, Toruń 2011, s. 179-182.

22 Zob. K. A. Paszkiewicz, Koncepcje powrotu do Europy we wspótczesnej polskiej myśli politycznej, [w:] Wspótczesna polska myśl polityczna, red. B. Pasierb, K. Paszkiewicz, Wrocław 1996, s. 25. B. Borowik, op. cit., s. 79.

23 B. Borowik, Ustrój państwa w polskiej publicystyce konserwatywnej lat dziewięćdziesiatych XX w., [w:] Między Europa naszych pragnień a Europa naszych możliwości, t. II, red. J. Faryś, T. Si- 
Jak sądzono, wejście do struktur europejskich pozwoliłoby Polsce (oraz państwom Europy Środkowej) na uniezależnienie się ekonomiczne (m.in. surowcowe) od Rosji ${ }^{24}$. Innym z kolei pozytywem, jakiego konserwatyści upatrywali w integracji europejskiej, był oczekiwany korzystny wpływ na relacje z zachodnim sąsiadem. Wspólne uczestniczenie w jednym politycznym projekcie zniwelować miało przewagę gospodarczą i polityczną Niemiec oraz przyczyniać się do podejmowania wzmożonej współpracy ${ }^{25}$.

Drugim, wspomnianym filarem oprócz struktur europejskich była potrzeba współpracy z paktem północnoatlantyckim. Zastrzegano jednak, iż NATO nie może, jak uważał chociażby Paweł Soloch, zastąpić całego myślenia o bezpieczeństwie państwa. Sam pakt powinien utrzymać dotychczasowe filary, jakimi były: kluczowa pozycja Stanów Zjednoczonych oraz sprzeciw wobec uczestnictwa w nim Rosji ${ }^{26}$.

Członkostwo w „natowskim” projekcie traktowano, jako podstawowy cel polskiej polityki bezpieczeństwa jednak nie postrzegano go „ani jako początek ani jako koniec" rozważań o ochronie państwa ${ }^{27}$. Koniecznym bowiem, w opinii konserwatystów, powinno być formułowanie obok „idei północnoatlantyckiej” innych alternatywnych źródeł bezpieczeństwa Rzeczypospolitej. Z tego też powodu oprócz myślenia tylko i wyłącznie pronatowskiego powinno się również rozważać inne opcje, jak chociażby rozwój relacji z niepodległą Ukrainą czy współpracę ze zjed noczonymi Niemcami ${ }^{28}$.

Oprócz podniesienia poziomu bezpieczeństwa uczestnictwo Polski w pakcie północnoatlantyckim, jak przewidywali konserwatyści instytucjonalni, wpływałoby na pozycję Polski na arenie międzynarodowej oraz na relacje z innymi państwami. Nowa sytuacja w szczególności oddziaływałaby na polskie stosunki z wschodnimi sąsiadami oraz byłaby gwarantem rzeczywistego z nimi partnerstwa ${ }^{29}$.

Za gwarancję bowiem odpowiednich relacji z wschodnimi partnerami uznawano „zakorzenienie” w strukturach paktu północnoatlantyckiego oraz struktu-

korski, P. Słowiński, Gorzów Wielkopolski 2007, s. 78-79. K. Paszkiewicz, op. cit., s. 25. A. Hall, Cywilizowana prawica, Ład Katolicki Tygodnik Społeczny 1992, nr 45, s. 1,4.

24 K. A. Paszkiewicz, op. cit., s. 26.

25 Zob. Stronnictwo Konserwatywno-Ludowe. Program, op. cit., s. 18.

26 P. Soloch, Polska i NATO, Kwartalnik Konserwatywny 1997, nr 2. s 26-28. Troska o bezpieczeństwo państwa zwracała także uwagę na przyszłość Paktu i jego relacje z Rosją w nowych okolicznościach jak m. in. zmniejszenie obecności USA w Europie. Szerzej zob.: A. Lewandowski, op. cit., s. 177-179.

27 Zob. P. Soloch, op. cit., s. 27-28.

28 Zob. ibidem, s. 29.

29 Zob. B. Komorowski, Wschodnie wyzwania, Myśl Konserwatywna 1997, nr 1, s. 121-124. 
rach europejskich. Osiągnięcie tej uprzywilejowanej pozycji dawało jeszcze jedną, szczególną korzyść dla Polski. Mianowicie pozycja taka pozwalała patrzeć na relacje polsko-rosyjskie z innej perspektywy, o wiele korzystniejszej. Bronisław Komorowski określił ją jako patrzenie na Moskwę niejako z „zewnątrz” niczym na jeszcze jednego ważnego partnera, a nie „jak na problem naszej opresji, z której musimy się wyrwać"30.

Ostatnim elementem proponowanej polityki zagranicznej była polska Ostpolitik, a w jej ramach relacje na linii Warszawa-Kijów. Ukraina w koncepcjach neokonserwatystów zajmowała kluczowe miejsce. Według Pawła Kowala, największy Polski wschodni sąsiad miał niebagatelny wpływ na znacznie międzynarodowe Polski, szczególnie ze względu na szanse uzależnienia się Kijowa od Moskwy ${ }^{31}$. Zasadniczą więc kwestią dla Polski, w ramach całej polityki wschodniej, powinno być zapewnienie stabilizacji Ukrainy jako samodzielnego państwa, „zorientowanego na zachód"32. Problemy w relacjach polsko-ukraińskich, co zauważano, nasilić się mogły wobec polskich działań integracyjnych z NATO oraz UE. Wtedy też bowiem relacje Warszawy z Kijowem stać się miały relacjami całego świata euroatlantyckiego. Konstatując, neokonserwatyści zauważali, iż relacje polsko-ukraińskie wymagają przełomu opartego nie tylko na deklaracjach politycznych ${ }^{33}$. Fakt ten podkreślał chociażby program SKL-u: „Sprawą szczególnej wagi jest dla Polski stabilizacja Ukrainy, jako samodzielnego, zorientowanego na Zachód i przyjaznego nam państwa. Obowiązkiem elit politycznych jest zjednać społeczne poparcie dla naszej polityki wobec Ukrainy" ${ }^{34}$.

Mimo ogromnego znaczenia Ukrainy, nie stanowiła ona jedynego podmiotu polityki wschodniej. Pozostałymi jej elementami wedle neokonserwatystów powinny być poszukiwania uregulowania stosunków z sąsiedzkimi państwami na wschodzie i innymi państwami powstałymi na gruzach ZSRR, obok Ukrainy szczególnie z Białorusią oraz Litwą. Priorytet powinny też mieć relacje z Rosją, z którą zawarcie ugody jawiło się jako sprawa kluczowa ${ }^{35}$.

Interesem bowiem Polski było, według programu SKL, aby stosunki z Rosją nie były obarczone urazami przeszłości i uprzedzeniami ${ }^{36}$. Jednocześnie, neokonserwatyści posiadali świadomość, iż w relacjach z Rosją należy prowadzić rzeczo-

\footnotetext{
30 Ibidem, s. 121-123.

31 P. Kowal, Ukraina przed wyborem, po wyborach, Kwartalnik Konserwatywny 2000, nr 6,
} s. $50-52$.

32 Stronnictwo Konserwatywno-Ludowe, Program, op. cit., s. 17-18.

33 P. Kowal, op. cit., s. 58-60.

34 Stronnictwo Konserwatywno-Ludowe. Program, op. cit., s. 18-19.

35 Ibidem. A. Hall, Cywilizowana prawica..., s. 8.

36 Stronnictwo Konserwatywno-Ludowe. Program, op. cit., s. 19. 
wy dialog, rozmawiać szczerze i otwarcie stawiać problemy natomiast współpracę traktować pragmatycznie ${ }^{37}$.

Osobliwe spostrzeżenie konserwatyści formułowali wobec Białorusi. Ponieważ nie ograniczali się wyłącznie do krytyki łamania praw człowieka i zasad państwa demokratycznego, ale zwracali uwagę by sprawa białoruska była pojmowana znacznie szerzej i obejmowała również kwestie gospodarcze i problem ekonomicznego kryzysu tego państwa. Dostrzegano bowiem możliwe tragiczne konsekwencje gospodarczej zapaści wschodniego sąsiada ${ }^{38}$.

Wobec znikomej skuteczności polskiej polityki wschodniej w relacjach z Białorusią środowisko „Koalicji Konserwatywnej” określiło główne przyczyny słabości tej polityki jako całej. Wedle Stanisława Górki był to wynik chaosu kompetencyjnego oraz braku koordynacji polskiej polityki wschodniej jako projektu politycznego ${ }^{39}$.

Negatywny wpływ na wschodni kierunek polskiej polityki miał również okres rządów koalicji Sojuszu Lewicy Demokratycznej i Polskiego Stronnictwa Ludowego w latach 1993-1997, kiedy to zakładano, że uda się osiągnąć dobre racje z Moskwą niejako „za personalne zasługi”. Okazało się jednak, iż Moskwa zdecydowała się na prowadzenie chłodnej, pragmatycznej polityki. Inaczej, jak zauważa Bronisław Komorowski było w okresie rządów solidarnościowych, czyli w latach 1989-1993 kiedy to nie tylko poszukiwano zabezpieczenia na Zachodzie, ale również dążono do uregulowania stosunków z wschodnimi sąsiadami ${ }^{40}$.

Receptą na niejako odnowienie wschodniego wymiaru polityki zagranicznej III RP mogła być koncepcja określona przez Pawła Kowala jako „Polska Wielka”. Jej sednem było, aby Rzeczpospolita uzyskała silną pozycję w ramach UE i NATO oraz odgrywała konkretną rolę w regionie Europy Środkowo-Wschodniej. Aby realizować powyższe plany koniecznym być powinno posiadanie silnej oferty ekonomicznej i kulturalnej ${ }^{41}$. Autor omawianej tu idei dostrzegał jednak kłopoty z realizowaniem polityki bilateralnej z państwami regionu: Czechami, Słowacją, Litwa, Węgrami oraz Rumunią. Bez osiągnięcia odpowiedniej pozycji w Europie Środkowej zrealizowanie polskich aspiracji na wschodzie stawało się niemożliwe. $\mathrm{Z}$ tego też powodu Polska powinna postawić przed sobą i realizować program

37 Zob. Między Rosja a NATO - rozmowa z Jerzym Markiem Nowakowskim, Przegląd Konserwatywny 1996, nr 5-8, s. 20-21.

38 Zob. K. Pastuszewski, Większy i mniejszy dramat Biatorusi, Przegląd Konserwatywny 1997, nr styczeń-marzec, s. 14.

39 Zob. S. Górka, Po pierwsze nie szkodzić. Szanse polskie polityki wobec Białorusi, Kwartalnik Konserwatywny 2000, nr 6, s. 66.

40 Zob. B. Komorowski, op. cit., s. 123.

${ }^{41}$ P. Kowal, O Polsce Wielkiej, Kwartalnik Konserwatywny 1999, nr 5, s. 136. 
zbudowania kluczowej pozycji wśród państw Europy Środkowej i Wschodniej. Podjęcie się takiego zadania powinno być „świadomą decyzją polityczną, opartą przynajmniej na minimalnej akceptacji opinii publicznej”. Dla wschodnich sąsiadów, jak uważał Kowal, Warszawa nadal jest ważnym ogniwem spajającym Morze Czarne z Bałtykiem. Jest rynkiem zbytu i realnym miejscem na ekonomiczną integrację z zachodem ${ }^{42}$, a istotne jest, aby za ekonomicznym znaczeniem wzrastała polityczna rola III RP w regionie.

Koncepcja „Polski Wielkiej” Pawła Kowala była tym samym, czym odwołanie się Bronisława Komorowskiego w polityce wschodniej do „odwiecznego polskiego horyzontu geograficznego", do Rzeczpospolitej Obojga Narodów, do idei prometeizmu wspieranej przez Józefa Piłsudskiego, czy wizji współpracy regionalnej Józefa Mierosławskiego ${ }^{43}$.

\section{Nurt chrześcijańsko-narodowy}

Zjednoczenie Chrześcijańsko-Narodowe jako główny przedstawiciel drugiego z omawianych tu nurtów formułowało propozycję polityki zagranicznej państwa polskiego określanej przez zapewnienie państwu niepodległości, zagwarantowanie bezpieczeństwa zewnętrznego oraz zajęcie właściwego miejsca w europejskiej rodzinie narodów. Wszystkie te cele, jak sugerowano, wymagały realnego podejścia do geopolitycznego położenia państwa ${ }^{44}$. Stanowisko Polski wobec „bloków polityczno-militarnych i ewentualnych sojuszów" powinno zatem wynikać z możliwości realizacji jej podstawowych celów ${ }^{45}$.

Przedstawiciele Zjednoczenia byli zwolennikami włączenia się Polski w proces integracji europejskiej. Jednocząca się Europa była jednak traktowana jako wspólnota ojczyzn w ramach której następowało „przezwyciężenie barier gospodarczych" natomiast polityczne zbliżenie narodów miało na celu jedynie stworzenie trwałej równowagi na kontynencie. W żadnym wypadku nie zgadzano się na taki model integracji, który mógłby ograniczać niepodległość państwową i suwerenność narodową ${ }^{46}$. Jak stanowiła deklaracja ideowa ZChN-u: „Po latach

42 Ibidem, ss. 135, 139-142.

43 B. Komorowski, op. cit., s. 122-123.

44 Program Zjednoczenia Chrześcijańsko-Narodowego (1990), [w:] Programy partii i ugrupowań parlamentarnych 1989-1991, cz. 1, red. I. Słodkowska, Warszawa 1995, s. 189.

45 Program wyborczy Zjednoczenia Chrześcijańsko Narodowego (1993), [w:] Wybory 1993. Partie i ich programy, red. I. Słodkowska, Warszawa 2001, s. 46.

46 Zjednoczenie Chrześcijańsko-Narodowe. Deklaracja Ideowa i Programowa, [w:] Programy partii i ugrupowań parlamentarnych 1989-1991, cz. 2, red. I. Słodkowska, Warszawa 1995, s. 98. 
przerwy spowodowanej zniewoleniem państwa dążymy do włączenia Polski w europejski system współpracy gospodarczej i budowę Europy ojczyzn. Pamiętamy równocześnie, że chrześcijańska Polska należała i należy do Europy budującej na uniwersalizmie chrześcijańskim - w myśl zasady «jedność w wielości», szanującej prawa wolnych narodów w ich suwerennych państwach. Taką Europę będziemy współtworzyć” ${ }^{37}$.

W ramach jednoczącej się Europy na znaczeniu zyskiwała kwestia miejsca Polski w regionie Europy Środkowej. Za zadanie Polski uznawano więc działanie na rzecz porozumienia państw regionu. Proces ten miał mieć wymiar polityki obronnej i gospodarczej ${ }^{48}$.

Nurt chrześcijańsko narodowy nie podnosił również sprzeciwu wobec przystąpienia Polski do NATO. Jak wskazuje Grzegorz Kucharczyk dołączenie do struktur paktu było postrzegane jako przekreślenie jałtańskiej zdrady i spełnienie marzeń wielu Polaków ${ }^{49}$. Podobnie wielce pozytywnie oceniano dobre relacje ze Stanami Zjednoczonymi. Sugerowano, iż dzięki nim Polska uniknie zależności od Niemiec lub Rosji oraz stanie się cennym sprzymierzeńcem, a co za tym, państwem o regionalnym znaczeniu, zdolnym do samodzielnego zaangażowania ${ }^{50}$. Myślenie o NATO według Mariana Piłki powinno być jednak wpisane w długookresową perspektywę rozwoju narodu uwzględniającą zmiany geopolitycznego położenia Polski oraz międzynarodowych uwarunkowań, w których Polska się znajduje $\mathrm{e}^{51}$.

Ważnym elementem koncepcji polityki zagranicznej była obecność Stanów Zjednoczonych na starym kontynencie. Pozytywami zaangażowania USA w Europie było, według Zjednoczenia, przeciwdziałanie próbom zastąpienia układu jałtańskiego nowymi strefami wpływów i aspiracjami hegemonistycznymi ${ }^{52}$. Wyobrażenie o roli USA w Europie oddaje poniższy cytat: „USA są czynnikiem stabilizacji i bezpieczeństwa na kontynencie europejskim. Stosunki polsko-amerykańskie mają też istotne znaczenie dla zachowania niezależności w naszych stosunkach z Europą Zachodnią" 53 .

47 Ibidem, s. 96. R. Czarnecki, Europa Ojczyzn. Rozmowa z Ryszardem Czarneckim, sekretarzem Akcji Wyborczej Solidarność ds. międzynarodowych, Tygodnik AWS 1997, nr 32, s. 16.

48 Zjednoczenie Chrześcijańsko-Narodowe. Deklaracja ideowa i programowa, op. cit., s. 98.

49 G. Kucharczyk, Polska myśl polityczna po 1939 roku, Dębogóra 2009, s. 193.

50 M. Jurek, Na czym zbudujemy Rzeczpospolita?, „Sprawa Polska” 1990, nr 1, s. 3.

51 M. Piłka, Zbudować silna Polskę. Rozmowa z prezesem Zjednoczenia Chrześcijańsko-Narodowego Marianem Pitka, Tygodnik AWS 1997, nr 35, s. 18-19.

52 Zjednoczenie Chrześcijańsko-Narodowe. Deklaracja ideowa i programowa, op. cit., s. 98.

53 Program wyborczy Zjednoczenia Chrześcijańsko-Narodowego (1990), op. cit., s. 47. 
Wizja zagranicznej polityki państwa, obok stosunku wobec dwóch projektów międzynarodowych, uzupełniona była o kwestię relacji z państwami Europy Zachodniej oraz Wschodniej. W przypadku drugiego z wymienionych tu kierunków program ZChN-u sugerował, że Polska powinna utrzymywać dobre stosunki z wszystkimi sąsiadami na Wschodzie, jednocześnie jednak dbając o prawa Polaków tam mieszkających ${ }^{54}$. Równie miarkowana była propozycja relacji z państwami Europy Zachodniej, z którymi powinna być rozwijana współpraca tak polityczna, jak i gospodarcza. Zaznaczano jednak, że w regionie Europy Środkowej polska polityka prowadzona miałaby być samodzielnie, co potwierdzałoby jej pozycję lidera w tej części Europy ${ }^{55}$.

Dopełnieniem omawianej tu koncepcji była kwestia relacji z Rosją oraz Niemcami. Zauważalna była ostrożność, z jaką przedstawiciele Zjednoczenia opisywali na początku lat 90. XX wieku relacje z oboma państwami. Niepewność dotycząca kierunków, w jakich pójść one mogły, obarczona była „realistycznym myśleniem geopolitycznym" sprawiała, iż obawiano się ewentualnego rosyjsko-niemieckiego zbliżenia oraz odrodzenia nastrojów imperialnych. W stosunku do wschodniego partnera zasadniczym postulatem było zapewnienie równowagi stosunków oraz zerwanie z wszelkimi reliktami systemu jałtańskiego "podporządkowującego politykę Polski, nasz system wojskowy i gospodarczy”. Wobec Niemiec wyrażano z kolei pragnienie współpracy w ramach Europy ojczyzn. Proces ten miał oprócz wzajemnego zbliżenia zapewnić również wykluczenie wszelkich dążeń „do tworzenia niemieckiej strefy wpływów w Europie środkowo-wschodniej” oznaczających zagrożenie dla Polski ${ }^{56}$.

\section{Nurt chadecki}

Cel, jaki stawiali przed polityką zagraniczną chadecy, to zapewnienie państwu suwerenności i niepodległości oraz „dążenie do wkomponowania Rzeczypospolitej w zorganizowane na demokratycznych zasadach struktury europejskie”. Specjalnym zadaniem państwa, podkreślanym przez każde ugrupowanie chadeckie było również wspieranie polaków za granicą ${ }^{57}$. Wyznaczając ramy dla polityki zagranicznej, zaznaczano, że polityka zagraniczna musi być powiązana z działaniami państwa polskiego na polach np. gospodarczych. Powinna ona uwzględniać po-

\footnotetext{
54 Program Zjednoczenia Chrześcijańsko-Narodowego (1993), op. cit., s. 46.

55 Ibidem.

56 Zjednoczenie Chrześcijańsko-Narodowe. Deklaracja ideowa i programowa, op. cit., s. 98-99.

57 Polskie Forum Chrześcijańsko-Demokratyczne. Zasady Programowe, op. cit., s. 67.
} 
czucie godności narodu i prowadzić do pełnej ochrony interesów kraju na arenie międzynarodowej oraz zapewnić dobre stosunki z innymi państwami, a w szczególności z sąsiadami ${ }^{58}$.

Pełne poparcie dla integracji z Wspólnotami Europejskimi było argumentowane przez alternatywę wyboru między Wschodem a Zachodem. Rezygnację $\mathrm{z}$ integracji utożsamiano z utraceniem wielkiej szansy rozwoju, ale i porzuceniem tradycyjnych i naturalnych powiązań oraz inspiracji kulturowych. Położenie geograficzne Polski wymagało tego, aby związać się z silnymi partnerami na Zachodzie. Dostrzegano również i argumenty ekonomiczne - wsparcie dla rolnictwa, inwestycje kapitałowe oraz rozwój technologiczny ${ }^{59}$. Jarosław Kaczyński ujmował to w następujący sposób: „Trzeba próbować wyrwać się ze strefy cywilizacyjnie zacofanej, jeżeli jest taka szansa”. Konstatował, że zostać na Wschodzie to „szaleństwo"60.

Pod pojęciem struktur europejskich nie rozumiano jedynie członkostwa we wspólnocie europejskiej, ale również uczestnictwo w tworzeniu wspólnot regionalnych ${ }^{61}$. Włączenie Polski do Europejskiej Wspólnoty Gospodarczej (EWG), czy jak najszybsze podjęcie współpracy z państwami Europejskiej Strefy Wolnego Handlu (EFTA) (jednak na zasadach, które pozwolą Polsce dostosować się do konkurencji międzynarodowej) oraz dążenia zmierzające do przystąpienia do NATO, były traktowane priorytetowo ${ }^{62}$. Niemniej jednak w ramach polskiego „zbliżania” się do Zachodu chadecy widzieli konieczność współpracy z innymi państwami, np. bałkańskimi czy też ówczesną Czechosłowacją. Taka współpraca, jak uważano gwarantowałoby silniejszą pozycję Polski i jednoczesne ograniczenie zagrożenia ze strony silnych i doświadczonych graczy europejskich ${ }^{63}$.

58 Ruch Dla Rzeczypospolitej. Program społeczno-gospodarczy, [w:] Wybory 1993. Partie i ich programy, red. I. Słodkowska, Warszawa 2001, s. 417.

59 K. Pawłowski, Wspólnota europejska czy Blok Międzymorza a może Imperium Jagiellońskie?, Ład. Katolicki Tygodnik Społeczny 1992, nr 23, s. 4.

60 J. Kaczyński, Wyrwać się. Z Jarosławem Kaczyńskim (Porozumienie Centrum) rozmawia Marcin Masny, Ład. Katolicki Tygodnik Społeczny 1993, nr 33, s. 3.

61 Partia Chrześcijańskich Demokratów. Program wyborczy [w:] Wybory 1991. Programy partii i ugrupowań politycznych, red. I. Słodkowska, Warszawa 2001, s. 281; Ruch Dla Rzeczypospolitej. Program spoteczno-gospodarczy, op. cit., s. 393; Polskie Forum Chrześcijańsko-Demokratyczne. Zasady Programowe, [w:] Programy Partii i ugrupowań parlamentarnych 1989-1991, t. 2, red. I. Słodkowska, Warszawa 1995, s. 67.

62 Partia Chrześcijańskich Demokratów. Program wyborczy, op. cit., s. 281-282; Deklaracja programowa Partii Chrześcijańskich Demokratów, [w:] Wybory 1993 Partie i ich programy, red. I. Słodkowska, Warszawa 2001, op. cit., s. 30.

63 C. Strzeszewski, Polska - Europa Środkowa - Europa, Ład. Katolicki Tygodnik Społeczny 1991, nr 7, s. 4. 
Zastrzegano również, że działania na rzecz integracji nie mogły stać w „sprzeczności z dbałością o zachowanie i rozwój polskiej kultury narodowej”. Procesy integracyjne powinny odbywać się przy poszanowaniu narodowych interesów i tradycji zgodnie z polską racją stanu ${ }^{64}$. Polska powinna uczestniczyć w Europie Ojczyzn, pojętej jako sfederowana wspólnota suwerennych państw i narodów we własnej tożsamości narodowej, historycznej i kulturowej ${ }^{65}$.

Procesy integracyjne nie mogły też zakłócać samodzielnych działań w zakresie polityki zagranicznej. Politycy Porozumienia Centrum konstatowali: „sprawą o podstawowym znaczeniu jest zapewnienie odpowiednich warunków dla prowadzenia spoistej polityki zagranicznej poprzez koncentrację środków na wybranych priorytetach, wzmocnienie służby dyplomatycznej oraz jej intelektualnego i materialnego zaplecza"66.

Wśród głosów poparcia znajdowały się również i uwagi krytyczne wobec integracji chociażby w kontekście negatywnej opinii na temat umowy o stowarzyszeniu z EWG, którą uważano za niekorzystną gospodarczo. Prognozowano, iż w jej wyniku wystąpią negatywne skutki ekonomiczne ${ }^{67}$. Zwracano również uwagę na problem certyfikacji wyrobów, który mógł zablokować polski eksport ${ }^{68}$.

Istniała wśród chadeków, również świadomość, że integracja z UE to także zagrożenie związane z sekularyzacją społeczeństw oraz możliwość zagubienia wartości tradycyjnych i narodowych. Optymistycznie zakładano jednak, że Polska mogła odwrócić ten trend ${ }^{69}$.

Skierowanie polskiej polityki zagranicznej ku Zachodowi nie mogło odbywać się kosztem najbliższych sąsiadów, ale również i polityki wschodniej-obie te sfery aktywności powinny się wzajemnie wspierać ${ }^{70}$. Polska powinna zatem zachować swoją pozycję na rynkach dawnego RWPG, gdzie szczególne znaczenie nadawano współpracy z Rosją Ukrainą, Litwą i Białorusią. W wymiarze gospodarczym

${ }^{64}$ Porozumienie Centrum - Zjednoczenie Polski, Program wyborczy, [w:] Wybory 1993. Partie i ich programy, red. I. Słodkowska, Warszawa 2001, s. 30; M. Gołaś, Wspótczesne partie chadeckie w Polsce, [w:] Chrześcijańska demokracja we wspótczesnym świecie, red. K. Krzywicka, E. Olszewski, Lublin 1999, s. 261.

${ }^{65}$ Partia Chrześcijańskich Demokratów. Program wyborczy, [w:] Wybory 1991. Programy partii i ugrupowań politycznych, red. I. Słodkowska, Warszawa 2001, s. 281; Ruch Dla Rzeczypospolitej. Program społeczno-gospodarczy, op. cit., s. 393; Polskie Forum Chrześcijańsko-Demokratyczne. Zasady Programowe, op. cit., s. 67; Deklaracja programowa Partii Chrześcijańskich Demokratów, op. cit., s. 68.

${ }_{66}$ Porozumienie Centrum - Zjednoczenie Polski, Program wyborczy, op. cit., s. 30.

67 Ruch Dla Rzeczypospolitej. Program spoteczno-gospodarczy, op. cit., s. 400-401

68 Ibidem, s. 420.

69 K. Pawłowski, Wspólnota europejska czy Blok Międzymorza a może Imperium Jagiellońskie?, Ład. Katolicki Tygodnik Społeczny 1992, nr 23, s. 4.

70 Politycy RDR ewentualne odwrócenie się od wschodu określali mianem błędu. Ruch Dla Rzeczypospolitej. Program społeczno-gospodarczy, op. cit., ss. 401 i 419. 
zwiększona aktywność na rynkach tych państw (określano, że stanowią one dla polskiej gospodarki nieograniczone możliwości handlowe) co pozwolić miałoby na normalizacje stosunków politycznych i społecznych. Polska powinna też zintensyfikować współpracę z krajami dalekiego wschodu ze względu na ewentualne szanse zasilenia kapitałowego i transferu nowoczesnych technologii do Polski ${ }^{71}$.

W kontekście relacji z najbliższymi sąsiadami Polski, chadecy proponowali zachowanie dobrych stosunków z wszystkimi i prowadzenie wobec nich polityki równowagi. Szczególnie ważne wydawało się przełamywanie uprzedzeń wobec Niemiec i państw powstałych po rozpadzie ZSRR. Krzysztof Pawłowski podkreślał znaczenie, ale i wymiar relacji z zachodnim sąsiadem w kontekście europejskich aspiracji Polski. Mówił on: „Nasza integracja z Europą, bez rezygnowania z naszej tożsamości i z tego, czym możemy wzbogacić Europę, nie może dokonać się bez prawdziwego pełnego pojednania z Niemcami”. Wspomniane pojednanie miałoby mieć miejsce zarówno na poziomie rządów, jak i narodów ${ }^{72}$.

Szczególnego znaczenia upatrywano również w relacjach z Ukrainą, w ramach, których należałoby wykorzystać jej zapotrzebowanie na wzorce zachowań demokratycznych, nowe technologie, a także skalę możliwości wynikających z polskoukraińskiej wymiany handlowej. Należało jednak być świadomym ewentualnych zagrożeń w postaci kryzysów politycznych i gospodarczych, które mogłyby wpłynąć na stosunki z Polską. Zagrożeniem mógł być również odradzający się ukraiński nacjonalizm. Dla dobra tych relacji powinny jednak ulec realizacji takie kwestie jak: pojednanie historyczne, wzajemna realizacja praw obywatelskich, współpraca gospodarcza i naukowa oraz szeroka współpraca na rzecz integracji z Europą byłych państw sowieckiego bloku ${ }^{73}$.

Poza Europą z kolei najważniejszym partnerem dla Rzeczypospolitej uznano Stany Zjednoczone Ameryki Północnej, które powinny nadal być obecne politycznie i militarnie w Europie, stabilizując sytuację polityczną a także zapewniając Polsce bezpieczeństwo ${ }^{74}$.

71 Partia Chrześcijańskich Demokratów. Program wyborczy, op. cit., s. 281-282; Deklaracja programowa Partii Chrześcijańskich Demokratów, op. cit., s. 69; Ruch Dla Rzeczypospolitej. Program spoteczno-gospodarczy, op. cit., s. 420.

72 K. Pawłowski, Polityka nie wystarczy. Z Krzysztofem Pawłowskim, przewodniczacym Zarzadu Głównego Partii Chrześcijańskich Demokratów rozmawia Jan M. Ruman, Ład. Katolicki Tygodnik Społeczny 1991, nr 9, s. 5.

73 W. Bojarski, Szansa i zagrożenie, Ład. Katolicki Tygodnik Społeczny 1991, nr 2, ss. 1, 4.

74 Partia Chrześcijańskich Demokratów. Program wyborczy, op. cit., s. 281; Ruch Dla Rzeczypospolitej. Program społeczno-gospodarczy, op. cit., s. 418-419; A. Mieczkowski, Wizja państwa w myśli politycznej Porozumienia Centrum (1990-1997), [w:] Myśl polityczna w Polsce po 1989 roku. Wybrane nurty ideowe, red. E. Maj, A. Wójcik, Lublin 2008, s. 159. 


\section{Podsumowanie}

Analizując i zestawiając ze sobą myśl polityczną poszczególnych nurtów polskiej prawicy należy stwierdzić, że w podstawowych wymiarach była ona ze sobą zbieżna. We wszystkich omówionych nurtach możemy znaleźć takie elementy patrzenia na międzynarodowe bezpieczeństwo jak:

- bliska współpraca ze Stanami Zjednoczonymi Ameryki;

- poparcie dla przystąpienia Polski do NATO i pełnienia w nim aktywnej roli;

- wschodnia polityka ujmowana jako jeden z dominujących elementów polityki polski;

- eurorealizm oraz patrzenie na integrację europejską jako współpracę suwerennych państw dbających o swój interes narodowy.

- potrzeba ułożenia poprawnch relacji z Moskwą

Poszczególne koncepcje różnicowały się dopiero na poziomie szczegółów. Można określić, że dotyczyły one raczej konkretnych rozwiązań np. w relacjach z Niemcami czy w obrębie Unii Europejskiej. Niekiedy jednak te drobne różnice stawały się przeszkodzą we współpracy poszczególnych nurtów. Przykładem, może być chociażby stosunek wymienionych nurtów do integracji europejskiej, gdzie dla każdego z nich zagrożenie dla tożsamości kulturowej Polaków było postrzegane w zupełnie różnym stopniu. 